\title{
Nutritional value of whole coconut, coconut powder, and coconut fiber treated with sodium hydroxide for sheep
}

\author{
Valor nutritivo do coco integral, pó de coco e fibra de coco \\ tratados com hidróxido de sódio para ovinos
}

\author{
José Cardoso de Araújo Neto', Fernando Yuri Brandão Fernandes'1, José Carlos Machado Pimentel², \\ Vânia Rodrigues Vasconcelos ${ }^{3 *}$, Márcia Mourão Ramos Azevedo ${ }^{4}$
}

\author{
${ }^{1}$ Universidade Federal do Piauí/UFPI, Teresina, PI, Brasil \\ ${ }^{2}$ Empresa Brasileira de Pesquisa Agropecuária/Embrapa, Agroindústria Tropical, Teresina, PI, Brasil \\ ${ }^{3}$ Universidade Federal do Piauí/UFPI, Departamento de Zootecnia, Teresina, PI, Brasil \\ 4Universidade Federal do Oeste do Pará/UFOPA, Instituto de Biodiversidade e Florestas/IBEF, Santarém, PA, Brasil \\ ${ }^{*}$ Corresponding author: vaniarvasconcelos@hotmail.com \\ Received in November 4, 2015 and approved in June 20, 2016
}

\begin{abstract}
The growing consumption of green coconut — fresh and industrialized — in Brazil generates a large volume of wastes and coproducts that justifies the search for alternatives for their use in animal feeding. The most limiting factor to the inclusion of these coproducts in ruminant diets is their high fiber content, which may restrict intake and performance. The present study determined the composition and in vitro dry matter degradability of whole coconut, coconut powder, and coconut fiber treated with sodium hydroxide $(0 \%, 3 \%$, and $6 \%)$ and the effect of including whole coconut hydrolyzed with $6 \%$ sodium hydroxide at different concentrations $(25 \%, 30 \%, 35 \%$, and $40 \%)$ in the diet on apparent digestibility of nutrients, performance, and feeding behavior of sheep. Alkalinization decreased the hemicellulose, NDF, and ADF contents of the evaluated coproducts. Whole coconut and coconut powder provided greater in vitro degradation of DM compared with coconut fiber, with highest values obtained with the inclusion of $6 \%$ sodium hydroxide. Inclusion of whole coconut in the diets did not affect the intakes of DM, CP, NDF, and ADF, but influenced weight gain, feed conversion, and apparent digestibility of DM and NDF. Regarding the feeding behavior of the animals, the inclusion of whole coconut in the diet only affected their rumination time. Whole coconut hydrolyzed with $6 \% \mathrm{NAOH}$ can be included in diets for feedlot sheep at up to $35 \%$ without reducing intake or weight gain.
\end{abstract}

Index terms: Cocos nucifera; $\mathrm{NaOH}$; coproduct.

\begin{abstract}
RESUMO
Avaliou-se a composição química e a degradação in vitro da matéria seca do coco integral, do pó de coco e da fibra de coco tratados com hidróxido de sódio $(\mathrm{NaOH})$ e o efeito da inclusão do coco integral hidrolisado com $6 \%$ de $\mathrm{NaOH}$ sobre a digestibilidade aparente dos nutrientes, o desempenho e o comportamento ingestivo em ovinos - $0 \%, 3 \%$ e $6 \%$ - e o efeito da inclusão do coco integral hidrolisado com $6 \%$ de hidróxido de sódio em diferentes concentrações na dieta - 25\%, 30\%, 35\% e 40\% - sobre a digestibilidade aparente dos nutrientes, o desempenho e o comportamento ingestivo, em ovinos. A alcalinização diminuiu os teores de hemicelulose, FDN e FDA dos coprodutos avaliados. O coco integral e o pó de coco apresentaram maior degradação in vitro da MS em relação a fibra de coco, com maiores valores obtidos com a inclusão de $6 \%$ de hidróxido de sódio. A inclusão de coco integral nas dietas não afetou o consumo de MS, de PB, de FDN e de FDA, mas influenciou o ganho de peso, a conversão alimentar e a digestibilidade aparente da MS e da FDN. Quanto ao comportamento ingestivo dos animais, só houve efeito de inclusão do coco integral na dieta sobre o tempo de ruminação. O coco tratado com $6 \%$ de $\mathrm{NaOH}$ pode ser utilizado em até $35 \%$ na dieta de ovinos, pois não reduz o consumo e o ganho de peso desses animais.
\end{abstract}

Termos para indexação: Cocos nucifera; $\mathrm{NaOH}$; coproduto.

\section{INTRODUCTION}

Brazil has more than 264 thousand hectares of land cultivated with coconut (Instituto Brasileiro de Geografia e Estatística - IBGE, 2015). Of this total cultivated area, over $80 \%$ are concentrated in the Northeast, and thus there has been an increase in consumption of both fresh and industrialized green coconut (Cocos nucifera) and in the production of wastes and coproducts in this region. Approximately $85 \%$ of the coconut structure consists of wastes that are not used by the agro-industrial chain for the generation of new products (Senhoras, 2004). Approximately 2.29 billion shells are produced annually in Brazil, which corresponds to 1.53 million tons of waste (Nunes et al., 2007). Also according to Nunes et al. (2007), most of the coconut shells are burned or discarded as waste; 
upon being burned, they produce substances that pollute the environment, and when discarded they constitute a proper means for procreation of venomous animals and disease-vector insects, becoming an environment pollutant.

The large volume of wastes generated by the agroindustry justifies the search for alternatives for the use of the green-coconut shell in the feeding of ruminants. The green-coconut waste can provide three coproducts: the whole coconut, the coconut fiber, and the coconut powder, which have different properties, especially regarding their particle size. Coconut fiber is obtained after the greencoconut shell is ground, and the powder is obtained after pressing and separation of the fibers. These wastes are rich in lignin and cellulose, with lignin content ranging from $37.2 \pm 0.8 \%$ to $43.9 \pm 0.7 \%$ and cellulose from $31.5 \pm 0.1 \%$ to $37.4 \pm 0.5 \%$ (Corradini et al., 2009).

Ruminants have the ability to use the fiber because of the activity of bacteria and protozoa present in their rumen that degrade the fibrous carbon to generate energy. However, when the percentage of fiber in the diet is increased, it can limit intake and affect the performance of animals. According to Mertens (1994), the neutral detergent fiber intake in ruminant diets should be $12 \mathrm{~g} / \mathrm{kg}$ $\mathrm{LW}$, varying by around $1 \mathrm{~g} / \mathrm{kg} \mathrm{LW}$. The NDF digestibility is also an important forage quality parameter, since diets with high values for the rumen-undegradable fibrous fraction increase the rumen-fill effect of the NDF from this forage (Detmann et al., 2003).

Foods rich in cell wall and with low quality can be treated as alkaline products, e.g., urea, ammonium, calcium oxide, and sodium hydroxide, to improve the effective degradation of DM and cell wall, resulting in better nutritive value (Garcez et al., 2014; Silva et al., 2014). These treatments are aimed mainly at the delignification of the cell wall through the solubilization of lignin.

Although the alkaline treatment provides an improvement in the fiber use and digestibility, if used as the only roughage, the speed of degradation in the rumen should be observed so that intake is not reduced, especially in ruminants with medium and high production potential (Romão et al., 2013). In this case, these authors indicate the need for increasing the amount of concentrate feed in the diet. The evaluation of high-fiber roughages from the nutritional perspective should include measurements of particle size, of the feeding behavior of animals, since it can interfere with their feeding, rumination, and idle activities (Carvalho et al., 2014).

The dietary complementation for ruminants during the dry seasons in arid and semi-arid regions is a hard task to rural producers. The use of green coconut fiber can be a satisfactory alternative during this period, but the low digestibility and the little palatability might limit voluntary intake (Senhoras, 2004). The lack of information about improvement of the nutritive value of this waste with the use of relatively cheap, easy chemical treatments accessible to producers and of the performance of animals fed diets with inclusion of this fiber has limited its use in ruminant feeding.

In this regard, in the present study, different coconut coproducts were treated with sodium hydroxide and evaluated with regard to chemical composition and in vitro digestibility, and later selected as the only roughage source to determine performance, in vivo digestibility, and feeding behavior of sheep.

\section{MATERIAL AND METHODS}

Two experiments were conducted - one in the Laboratory of Animal Nutrition and another at the Department of Animal Science of Universidade Federal do Piauí (UFPI). The utilized material was collected in green-coconut processing industries located in Fortaleza, CE, Brazil. The coproducts whole coconut, coconut fiber, and coconut powder were obtained after collecting the green-coconut shells from the industries and the grinding, pressing, selection, fiber-sieving, and, lastly, partial natural dehydration procedures.

\section{Chemical composition and in vitro digestibility}

For the chemical hydrolysis, coproducts were sprayed with a solution of sodium hydroxide $(\mathrm{NaOH})$ at three concentrations: $0 \%, 3 \%$, and $6 \%$ at the rate of $1 \mathrm{~kg}$ of coproduct for $1 \mathrm{~kg}$ of solution, according to the treatment. Subsequently, the coproducts were homogenized and packed in plastic bags for $48 \mathrm{~h}$ at room temperature (Pires et al., 2006).

Samples of the hydrolyzed coproducts had their dry matter (DM), organic matter (OM), crude protein (CP), and ether extract (EE) contents determined according to methods described in Association of Official Analytical Chemists - AOAC (1995); and neutral detergent fiber (NDF), acid detergent fiber (ADF), using amylase, and hemicellulose, to Van Soest et al. (1991). A Dayse incubator was used for the estimate of the in vitro DM digestibility (IVDMD), in accordance with Santos et al. (2000), using a bovine rumen inoculum from a 5-yearold adult rumen-cannulated male animal weighing 600 $\mathrm{kg}$ that received a maintenance diet (National Research Council - NRC, 2001) containing whole coconut. After 48 
$\mathrm{h}$ of incubation, samples were removed from the incubator and bags were washed in running water. Later, they were washed with an NDF solution to remove microorganisms adhering to the residual particles. The IVDMD was calculated as the ratio between the amount of residual DM and the initial DM: IVDMD $(\% \mathrm{DM})=100[($ initialDM $)$ - (residualDM - blank)/initialDM].

The concentrate was formulated based on ground corn, soybean meal, urea, and mineral premix. Diets were calculated to be isoproteic and to contain sufficient nutrients to provide gains of more than $150 \mathrm{~g} /$ day, according to NRC (2007) (Table 1).

Table 1: Proportion of ingredients and composition of experimental diets, in \% DM.

\begin{tabular}{ccccc}
\hline \multirow{2}{*}{ Ingredient } & \multicolumn{5}{c}{ Diet (\% of $\mathrm{WC}_{6 \% \mathrm{NaOH}}$ ) } \\
\cline { 2 - 5 } & \multicolumn{1}{c}{25} & \multicolumn{1}{c}{35} & \multicolumn{1}{c}{40} \\
\hline Corn & 55.3 & 51.3 & 50.9 & 50.5 \\
Soybean meal & 18.4 & 17.1 & 17.0 & 16.8 \\
WC $_{6 \% \mathrm{NaOH}}$ & 25 & 30 & \multicolumn{1}{c}{35} & \multicolumn{1}{c}{40} \\
Urea & 0.2 & 0.6 & 1.1 & 1.6 \\
Premix & 1 & 1 & 1 & 1 \\
\hline Composition & & & & \\
\hline Dry matter & 87.3 & 87.3 & 87.4 & 87.5 \\
Crude protein & 14.3 & 14.4 & 15.1 & 14.6 \\
Ether extract & 3.3 & 3.3 & 3.2 & 3.2 \\
Neutral detergent fiber & 29.1 & 32.1 & 32.9 & 36.2 \\
Acid detergent fiber & 19.9 & 22.5 & 24.6 & 27.8 \\
Mineral matter & 5.5 & 6.2 & 6.4 & 6.8 \\
\hline
\end{tabular}

WC $_{6 \% \mathrm{NaOH}}$ : whole coconut hydrolyzed with $6 \%$ sodium hydroxide.

(1) Provides per kg of product: calcium $120 \mathrm{~g}$, phosphorus $87 \mathrm{~g}$, sodium $147 \mathrm{~g}$, manganese 1,300 mg, zinc 3,800 mg, iron $18,000 \mathrm{mg}$, cobalt $40 \mathrm{mg}$, iodine $80 \mathrm{mg}$, chromium $20 \mathrm{mg}$, molybdenum $300 \mathrm{mg}$, sodium monensin 1,300 $\mathrm{mg}$, fluorine $870 \mathrm{mg}$, and selenium $15 \mathrm{mg}$.

\section{Performance, in vivo digestibility and feeding behavior of sheep}

Twenty Santa Inês $\times$ Dorper crossbred male sheep with an average age of 90 days and average live weight of $20 \pm 2.9 \mathrm{~kg}$ were kept in individual $1 \mathrm{~m}^{2}$ stalls with concrete floor covered with wood shavings and provided with feeders and drinkers. Feed was provided in two daily meals, at $08 \mathrm{~h} 00$ and $16 \mathrm{~h} 00$, allowing for $10 \%$ as orts. The adjustment was made according to the consumption of the animals, by weighing the orts directly. Animals received water freely during the entire experimental period. Animals were weighed at the beginning of the performance trial and every 7 days, always before the first daily meal. Upon completing 47 days in the experimental period, sheep were weighed to determine final body weight. Approximately $10 \%$ of feed and orts were collected daily as a sample, packed, and stored for later analyses. To determine the DM, OM, CP, NDF, ADF, and hemicellulose contents, samples were initially pre-dried in a forced-air oven at $55^{\circ} \mathrm{C} \pm 5{ }^{\circ} \mathrm{C}$ and ground.

Two days before the end of the performance trial, the time spent feeding, ruminating, and on other activities (idleness, drinking, defecation, and urination) was recorded during $24 \mathrm{~h}$ straight, in five-minute intervals, according to Carvalho et al. (2007). During the night time observation, the environment was maintained under artificial illumination.

The apparent digestibility coefficients of DM, CP, $\mathrm{NDF}$, and ADF were calculated soon after the performance trial by the total feces collection method, using metabolic cages, lasting eight days, which consisted of three for adaptation and five for feces collection (Bueno et al., 2005). Animals were fed twice daily, at $09 \mathrm{~h} 00$ and $16 \mathrm{~h} 00$, allowing $10 \%$ as orts. Orts, feces, and urine were collected daily, per animal, and a $10 \%$ aliquot was taken, packed, and stored for later analyses. For the laboratory analyses, samples were pre-dried and ground. The apparent digestibility coefficients of the nutrients (DC) were determined according to the equation described by Schneider and Flatt (1975), as follows: DC $=100$ [(nutrient consumed - nutrient excreted)/ nutrient consumed].

The total digestible nutrients (TDN) were determined based on the apparent digestibility coefficient of DM (DMD), according to the equation proposed by Cappelle et al. (2001): TDN $=1.064 \times \mathrm{DMD}-3.84$.

To analyze the chemical and IVDMD data, a completely randomized design was adopted, in a $3 \times$ 3 factorial arrangement (three coproducts and three concentrations of $\mathrm{NaOH}$, with nine treatments and four replicates. After the interaction between coproducts and levels of inclusion of $\mathrm{NaOH}$ was detected, the regression analysis was performed considering the inclusion levels within each by-product. Data were subjected to analysis of variance, using the PROC GLM procedure of Statistical Analysis System - SAS (2009), statistical software, and means were compared by least significant differences of Tukey's test at 5\% significance. Performance, feeding behavior, and apparent-digestibility data were analyzed in a randomized-block design with four treatments, using 
SAS (2009) software, with means compared by Duncan's test at $5 \%$ probability level.

\section{RESULTS AND DISCUSSION}

There was no interaction $(\mathrm{P}>0.05)$ between coproducts and percentages of inclusion of $\mathrm{NaOH}$ for $\mathrm{OM}$, $\mathrm{CP}$, or hemicellulose. Therefore, the effects were studied separately for each one of these variables (Table 2).

Among the coproducts, the coconut fiber displayed the highest $(\mathrm{P}>0.05)$ concentration of $\mathrm{OM}$ and hemicellulose and the lowest $(\mathrm{P}<0.05)$ amount of $\mathrm{CP}$. The decrease $(\mathrm{P}<0.05)$ in the percentage of $\mathrm{OM}$ as the concentration of $\mathrm{NaOH}$ was increased was expected due to the higher addition of $\mathrm{Na}$. The higher $\mathrm{CP}$ content obtained with the higher $\mathrm{NaOH}$ concentration $(\mathrm{P}<0.05)$ was a result of the release of protein bound to the plant cell wall or the fiber. This effect was associated with the reduction of
$\mathrm{NDF}, \mathrm{ADF}$, and hemicellulose contents, which proves the solubilization of the plant cell wall.

No interaction occurred $(\mathrm{P}<0.05)$ between coproducts and the hydrolysis level for NDF, ADF, or IVDMD, and thus the regression analysis was performed considering the inclusion levels within each coproduct (Figures 1, 2, and 3). The decrease in NDF contents for the three coproducts with the alkalinization can be attributed to the partial solubilization of the cell wall. The magnitude of this effect was more expressive in the treatment with the highest concentration of $\mathrm{NaOH}$. Gomes et al. (2015) also found that sodium hydroxide was efficient in delignifying the cell wall of sugarcane bagasse. Addition of $\mathrm{NaOH}$ to whole coconut and coconut powder resulted in a greater reduction of the NDF content when compared with that observed by Pires et al. (2006) with sugarcane, who obtained a decrease of only 1.15 units of NDF per unit of $\mathrm{NaOH}$ added.

Table 2: Mean values for organic matter (OM), crude protein (CP), and hemicellulose of whole coconut, coconut powder, and coconut fiber and of the coproduct treated with different percentages of sodium hydroxide $(\mathrm{NaOH})$.

\begin{tabular}{cccccrc}
\hline \multirow{2}{*}{ Variable \% } & \multicolumn{3}{c}{ Coproduct } & \multicolumn{3}{c}{$\mathrm{NaOH}(\%)$} \\
\cline { 2 - 6 } & Whole coconut & Coconut powder & Coconut fiber & 0 & \multicolumn{1}{c}{3} \\
\hline OM & $92.0 \mathrm{~b}$ & $90.8 \mathrm{c}$ & $94.5 \mathrm{a}$ & $96.0 \mathrm{a}$ & $92.4 \mathrm{~b}$ & $88.9 \mathrm{c}$ \\
$\mathrm{CP}$ & $3.9 \mathrm{~b}$ & $4.9 \mathrm{a}$ & $3.3 \mathrm{c}$ & $3.3 \mathrm{~b}$ & $3.3 \mathrm{~b}$ & $4.0 \mathrm{a}$ \\
Hemicellulose & $14.0 \mathrm{~b}$ & $15.6 \mathrm{~b}$ & $19.0 \mathrm{a}$ & $18.4 \mathrm{a}$ & $15.5 \mathrm{ab}$ & $14.6 \mathrm{~b}$ \\
\hline
\end{tabular}

*Different lowercase letters in the same row indicate a significant difference (Tukey's test, $\mathrm{P}<0.05$ ).

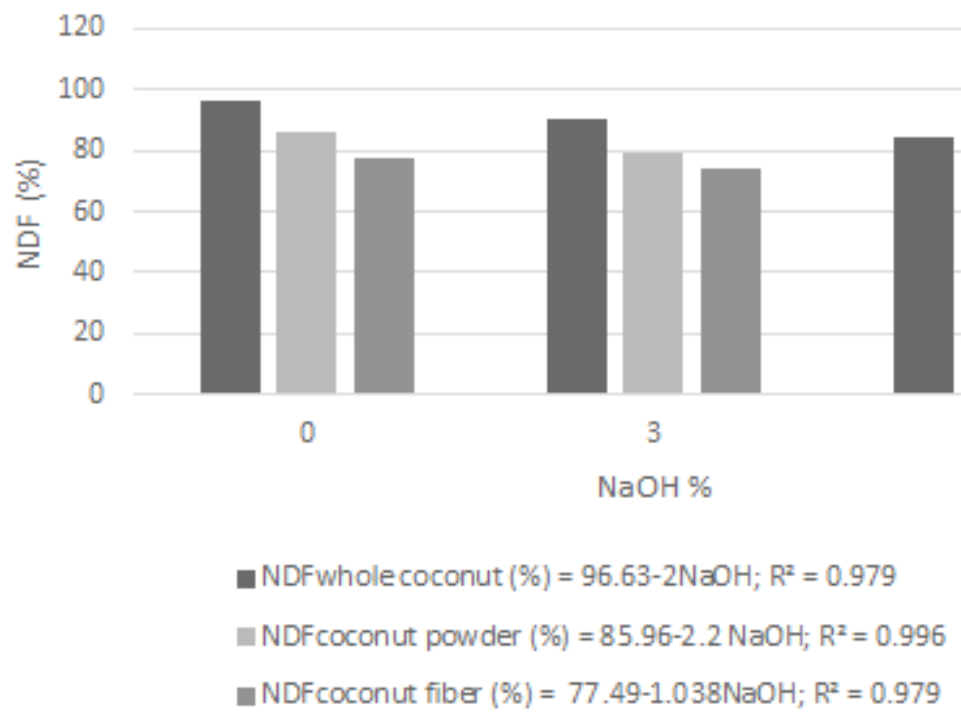

Figure 1: Neutral detergent fiber (NDF) contents of whole coconut, coconut powder, and coconut fiber hydrolyzed with sodium hydroxide $(\mathrm{NaOH})$. 


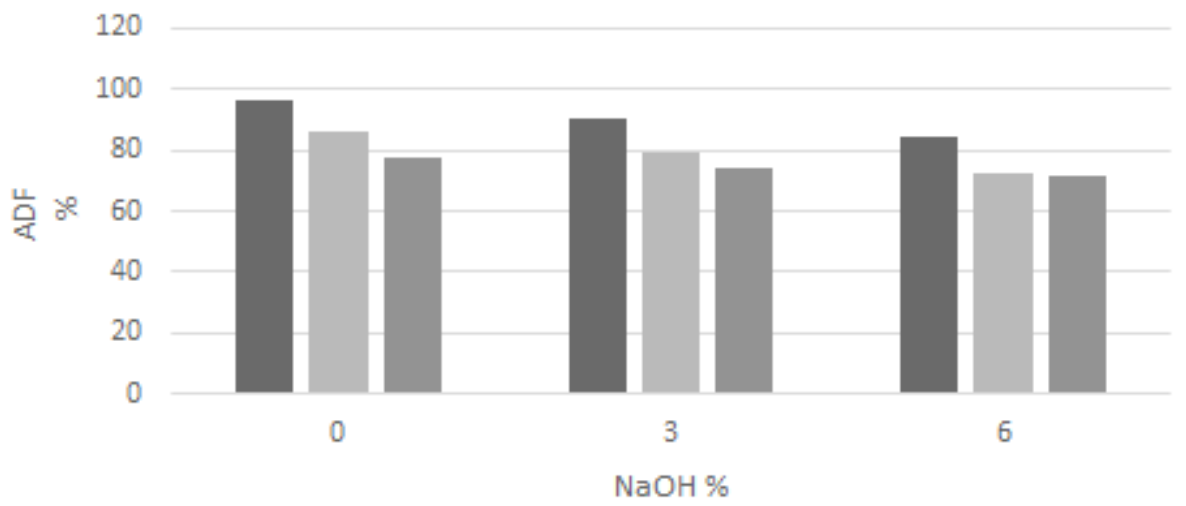

\footnotetext{
- ADFwhole coconut $\left(\%=75.81-1.38 \mathrm{NaOH} ; \mathrm{R}^{2}=0.917\right.$

ADFcoconut powder $(\%)=67.01-1.07 \mathrm{NaOH} ; \mathrm{R}^{2}=0.994$

aDFcoconut fiber $(\%)=63.06-0.89 \mathrm{NaOH} ; \mathrm{R}^{2}=0.842$
}

Figure 2: Acid detergent fiber (ADF) contents of whole coconut, coconut powder, and coconut fiber hydrolyzed with sodium hydroxide $(\mathrm{NaOH})$.

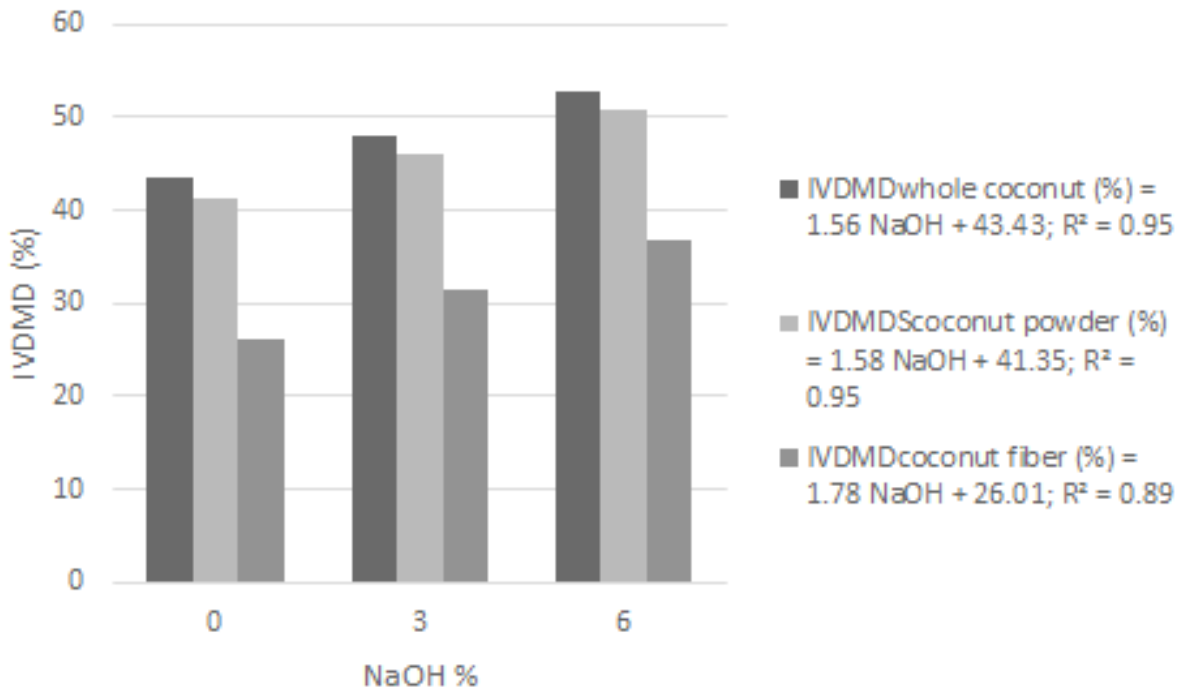

Figure 3: In vitro dry matter degradation (IVDMD) of whole coconut, coconut powder and coconut fiber hydrolyzed with sodium hydroxide $(\mathrm{NaOH})$.

Likewise, the ADF content was reduced with the alkaline treatments. The whole coconut showed a lower $(\mathrm{P}<0.05)$ percentage of ADF relatively to the coconut powder and coconut fiber. The magnitude of the decrease in the concentration of ADF depended on the dose of $\mathrm{NaOH}$ utilized. Murta et al. (2011) observed that the treatment of sugarcane bagasse with increasing levels of sodium hydroxide decreased its NDF and ADF concentrations linearly, and that a dose greater than $2 \%$ increased the availability of cell wall due to its partial solubilization.

The whole coconut and the coconut powder showed a higher IVDMD $(\mathrm{P}<0.05)$ compared with the coconut fiber; irrespective of the coproduct, the inclusion of $6 \% \mathrm{NaOH}$ resulted in a higher IVDMD. This is the result of the delignification and partial solubilization of hemicellulose and the expansion of hemicellulose - a 
linear decrease observed in the NDF and ADF contents - which facilitated the attack of the cell wall by fibrolytic microorganisms.

The addition of one unit of $\mathrm{NaOH}$ provided an increase of 1.56, 1.58, and 1.78 units in the IVDMD of the whole coconut, coconut powder, and coconut fiber, respectively. The IVDMD of the whole coconut and of the coconut powder treated with $6 \% \mathrm{NaOH}$ were higher than $50 \%$, but the highest increase in IVDMD was obtained with coconut fiber, $41.1 \%$. It is thus observed that alkaline hydrolysis benefited the nutritional value of these coproducts and can predispose animals to satisfactory performances when included in diets. Gomes et al. (2015) also obtained an elevation of more than 50\% in the IVDMD of hydrolyzed sugarcane bagasse and attributed this effect to the partial solubilization of lignin; it also reduced the effect of this physical barrier for the degradation of the structural carbohydrates by the rumen microorganisms.

For the performance, apparent digestibility, and feeding behavior trials, the whole coconut treated with $6 \% \mathrm{NaOH}\left(\mathrm{WC}_{6 \% \mathrm{NaOH}}\right)$ was used as the only roughage in the sheep diets, as it presented the best chemical and fermentation characteristics compared with the coconut fiber, and also because of its lower cost relatively to the coconut powder.

Daily dry matter intake in percentage and per unit of metabolic size in the diets did not differ $(\mathrm{P}>0.05)$ from each other despite the increase in the concentration of NDF, which is one of the main factors controlling DMI (Table 3). It is believed that the intake was not affected by the inclusion of $\mathrm{WC}_{6 \% \mathrm{NaOH}}$ due to the improvement in the fiber digestion with the alkaline agent. The DMI in $\mathrm{g} /$ day were higher than the $82.37 \mathrm{~g} /$ unit of metabolic weight found by Azevedo et al. (2012) with sheep fed a diet containing 30\% roughage and $70 \%$ concentrate.

Likewise, the percentage increase in $\mathrm{WC}_{6 \% \mathrm{NaOH}}$ in the diets did not affect $(\mathrm{P}>0.05)$ the crude protein intake (CPI), possibly due to the low $\mathrm{CP}$ content of $\mathrm{WC}_{6 \% \mathrm{NaOH}}$ and because the diets were isoproteic. The intakes of NDF (NDFI) and ADF (ADFI) did not differ $(\mathrm{P}>0.05)$ between the diets; the lack of effects for DM intake might have contributed for this effect not to occur.

The DWG of the animals fed the diet containing $25 \% \mathrm{WC}_{6 \% \mathrm{NaOH}}$ was higher than that observed with $40 \%$ of inclusion, which resulted in a better $(\mathrm{P}<0.05)$ feed conversion. For the diet with $25 \% \mathrm{WC}_{6 \% \mathrm{NaOH}}$, DWG was higher than the $205 \mathrm{~g}$ observed by Azevedo et al. (2012) using tropical grasses as roughage with a roughage:concentrate ratio of 30:70 in the diet. The low NDF content and the higher energy uptake with the increased level of concentrate in this diet contributed to this result. Overall, the performance data observed with the diets containing $\mathrm{WC}_{6 \% \mathrm{NaOH}}$ were close to those observed with diets containing tropical grasses, between 104 and 194 $\mathrm{g} / \mathrm{d}$ (Carvalho et al., 2006), or agro-industrial coproducts, from 195 to $228 \mathrm{~g} / \mathrm{d}$ (Murta el al., 2011). This demonstrates this coproduct's capacity of being used as a roughage source in high-concentrate diets. Feed conversion ranged from 4.7 to 7.7 and was negatively $(\mathrm{P}<0.05)$ influenced $(\mathrm{P}<0.05)$ by the $\mathrm{WC}_{6 \% \mathrm{NaOH}}$ inclusion levels, showing that the animals will need to consume greater amounts of feed to convert it to $1 \mathrm{~kg} \mathrm{LW}$. The same response was found by Azevedo et al. (2012), who detected a linear increase in feed conversion values as they increased the levels of macauba palm (Acrocomia aculeata) cake in finishingsheep diets, with values ranging from 5.5 to 6.4 .

Table 3: Intakes of dry matter (DMI), crude protein (CPI), neutral detergent fiber (NDFI), and acid detergent fiber (ADFI), daily weight gain (DWG), and feed conversion (FC) in sheep fed diets containing four levels of whole coconut hydrolyzed with $6 \%$ sodium hydroxide $\left(\mathrm{WC}_{6 \% \mathrm{NaOH}}\right)$.

\begin{tabular}{|c|c|c|c|c|c|}
\hline \multirow{2}{*}{ Parameter } & \multicolumn{4}{|c|}{$\mathrm{WC}_{6 \% \mathrm{NaOH}}(\%)$} & \multirow{2}{*}{ CV \% } \\
\hline & 25 & 30 & 35 & 40 & \\
\hline DMI (g/day) & 1,008 & 985 & 1,039 & 892 & 16.5 \\
\hline DMI (g DM/kg ${ }^{0.75}$ ) & 92.2 & 105.7 & 81.0 & 90.9 & 20.6 \\
\hline CPI (g/day) & 146 & 145 & 162 & 135 & 16.7 \\
\hline NDFI (g/day) & 283 & 298 & 314 & 296 & 14.9 \\
\hline ADFI (g/day) & 190 & 205 & 232 & 225 & 16.5 \\
\hline DWG (g/day) & $220 a$ & $168 a b$ & $170 a b$ & $131 b$ & 33.1 \\
\hline FC (kg feed/LWG) & $4.7 \mathrm{a}$ & $5.9 a b$ & $6.2 \mathrm{ab}$ & $7.7 \mathrm{~b}$ & 24.4 \\
\hline
\end{tabular}

$a, b$ Different letters in the same row indicate a significant difference (Duncan's test, $\mathrm{P}<0.05$ ). 
The apparent digestibility of DM (DMD) differed $(\mathrm{P}<0.05)$ between the diets with $25 \%$ and $35 \%$ or $40 \%$ $\mathrm{WC}_{6 \% \mathrm{NaOH}}$ (Table 4); between the diets with $25 \%$ and $40 \% \mathrm{WC}_{6 \% \mathrm{NaOH}}$, this difference was $7.3 \%$. The apparent digestibility of OM (OMD) was higher $(\mathrm{P}<0.05)$ in the diet with $25 \% \mathrm{WC}_{6 \% \mathrm{NaOH}}$. Addition of whole coconut did not interfere $(\mathrm{P}<0.05)$ with $\mathrm{CPD}$ because the diets were isoproteic and because the concentrate contributed with the largest part of the dietary protein, since the whole coconut has a low CP content.

For NDF, the diet treated with $25 \% \mathrm{WC}_{6 \% \mathrm{NaOH}}$ showed higher values than that treated with $40 \%$, but this effect was not sufficient to cause a rumen-fill effect, since it did not affect intake. This difference may be attributed to the lower percentage of NDF in this diet due to the lower proportion of roughage. For ADFD, however, no difference was detected (P $>0.05$ ) between the diets, possibly due to the action of the sodium hydroxide on the cell wall, facilitating its attack by rumen microorganisms. In an experiment with sheep fed $50 \%$ sugarcane treated with $2.25 \%$ calcium oxide and 50\% concentrate, Murta et al. (2011) obtained values close to those observed here with whole coconut for DMD, NDFD, and ADFD: $72.9 \%, 32.3 \%$ and $30.7 \%$, respectively. The diet with the highest $(\mathrm{P}>$ 0.05 ) TDN content was that with $25 \%$ of inclusion of whole coconut, which can be explained by the higher proportion of concentrate. The DWG obtained with this diet was higher than that found by Xenofonte et al. (2008) using a diet containing 71\% TDN.

As regards the feeding behavior, there was no effect $(\mathrm{P}<0.05)$ of treatment on the time spent feeding (Table 5). The equal intakes of DM, CP, and NDF may explain the similarity between the times. Sá et al. (2015) evaluated the feeding activity of sheep fed diets with increasing inclusion levels of babassu (Attalea speciosa) cake and also did not find differences between feeding times. These authors attributed this result to the fact that the diets were isonitrogenous and isofibrous, along with the equal DM intakes.

Table 4: Apparent digestibility of dry matter (DMD), organic matter (OMD), crude protein (CPD), neutral detergent fiber (NDFD), and acid detergent fiber (ADF), and total digestible nutrients (TDN) in sheep fed diets containing four levels of whole coconut hydrolyzed with $6 \%$ sodium hydroxide $\left(\mathrm{WC}_{6 \% \mathrm{NaOH}}\right)$.

\begin{tabular}{|c|c|c|c|c|c|}
\hline \multirow{2}{*}{ Parameter } & \multicolumn{4}{|c|}{$\mathrm{WC}_{6 \% \mathrm{NaOH}}(\%)$} & \multirow{2}{*}{$\mathrm{CV} \%$} \\
\hline & 25 & 30 & 35 & 40 & \\
\hline DMD (\%) & $69.8 \mathrm{a}$ & $66.7 a b$ & $65.1 b$ & $64.7 b$ & 3.3 \\
\hline OMD (\%) & $71.3 a$ & $67.3 b$ & $65.4 b$ & $64.9 b$ & 3.3 \\
\hline CPD (\%) & 63.9 & 61.8 & 64.2 & 64.8 & 4.7 \\
\hline NDFD (\%) & $36.3 a$ & $34.6 a b$ & $35.4 a$ & $27.5 b$ & 16.8 \\
\hline ADFD (\%) & 23.9 & 20.7 & 21.1 & 21.1 & 14.4 \\
\hline TDN & $71.3 a$ & $67.2 b$ & $65.5 b$ & $65.0 \mathrm{~b}$ & 3.4 \\
\hline
\end{tabular}

a,b Different letters in the same row indicate a significant difference (Duncan's test, $\mathrm{P}<0.05$ ).

Table 5: Feeding behavior of sheep fed diets containing four levels of whole coconut hydrolyzed with 6\% sodium hydroxide $\left(\mathrm{WC}_{6 \% \mathrm{NaOH}}\right)$.

\begin{tabular}{|c|c|c|c|c|c|}
\hline \multirow{2}{*}{ Parameter } & \multicolumn{4}{|c|}{$\mathrm{WC}_{6 \% \mathrm{NaOH}}(\%)$} & \multirow{2}{*}{ CV \% } \\
\hline & 25 & 30 & 35 & 40 & \\
\hline Feeding (\% in $24 \mathrm{~h}$ ) & 15.5 & 13.2 & 13.3 & 14.5 & 21.8 \\
\hline Rumination (\% in $24 \mathrm{~h}$ ) & $31.6 b$ & $36.2 \mathrm{ab}$ & $40.3 a$ & 33.9ab & 13 \\
\hline Other activities (\% in $24 \mathrm{~h}$ ) & 52.9 & 50.6 & 46.4 & 51.6 & 12.8 \\
\hline
\end{tabular}

a,b Different letters in the same row indicate a significant difference (Duncan's test, $\mathrm{P}<0.05$ ). 
Rumination time was longer $(\mathrm{P}<0.05)$ by the animals fed the diet containing $35 \%$ whole coconut as compared with those consuming the diet with $25 \%$ of that ingredient, likely due to the greater NDF content of the diet (Carvalho et al., 2014). Sá et al. (2015) also found an effect of the NDF from babassu cake on the feeding behavior of lambs; with the inclusion of babassu cake in the diet, the sum of the times spent feeding and ruminating resulted in a longer chewing time. However, Cardoso et al. (2006) evaluated diets for sheep with increasing NDF levels - between $25 \%$ and $43 \%$ and did not observe an effect on the time spent feeding, ruminating, and on other activities. When the rumination and chewing times are limited, saliva production is decreased, which may lead to a decline of the rumen $\mathrm{pH}$ and consequently a reduction of the fiber digestibility (Macedo et al., 2007). This reduction was not observed, since the DNDF in the diet with $25 \% \mathrm{WC}_{6 \% \mathrm{NaOH}}$ did not differ from that with $35 \%$ of this ingredient, despite the shorter rumination time.

The time spent on other activities did not differ $(\mathrm{P}<0.05)$ between treatments, though differences were found in rumination time between the treatments with 25 and $35 \% \mathrm{WC}_{6 \% \mathrm{NaOH}}$. As stated by Gonçalves et al. (2001), the longer times spent feeding or ruminating may lead to a reduction of the time spent on other activities, such as idleness.

\section{CONCLUSION}

Coconut treated with $6 \% \mathrm{NaOH}$ can be used at up to $35 \%$ in sheep diets, as it does not decrease the intake or weight gain of these animals.

\section{ACKNOWLEDGMENTS}

To Banco do Nordeste "ETENE/FUNDECT", for the financial support.

\section{REFERENCES}

ASSOCIATION OF OFFICIAL ANALYTICAL CHEMISTS - AOAC. Official Methods of Analysis, Arlington, Virginia, USA, 1995.

AZEVEDO, A. et al. Desempenho de cordeiros alimentados com inclusão de torta de macaúba na dieta. Pesquisa agropecuária brasileira, 47(11):1663-1668, 2012.

BUENO, I. C. S. et al. Influence of inoculum source in a gas production method. Animal Feed Science and Technology, 123(124):95-105, 2005.
CAPPELLE, E. R. et al. Estimativas do valor energético a partir de características químicas e bromatológicas dos alimentos. Revista Brasileira de Zootecnia, 30(6):18371856, 2001.

CARDOSO, A. R. et al. Comportamento ingestivo de cordeiros alimentados com dietas contendo diferentes níveis de fibra em detergente neutro. Ciência Rural, 36(2):604609, 2006.

CARVALHO, S. et al. Desempenho e características da carcaça de cordeiros mantidos em pastagem de tifton-85 e suplementados com diferentes níveis de concentrado. Revista Brasileira de Agrociência, 12(3):357-361, 2006.

CARVALHO, G. G. P. et al. Aspectos metodológicos do comportamento ingestivo de ovinos alimentados com capim-elefante amonizado e subprodutos agroindustriais. Revista Brasileira de Zootecnia, 36(4):1105-1112, 2007.

CARVALHO, S. et al. Comportamento ingestivo de cordeiros Texel e Ideal alimentados com casca de soja. Archivos de Zootecnia, 63(241):55-64, 2014

CORRADINI, E. et al. Composição química, propriedades mecânicas e térmica da fibra de frutos de cultivares de coco verde. Revista Brasileira de Fruticultura, 31(3):837846, 2009.

DETMANN, E. et al. Consumo de fibra em detergente neutro por bovinos em confinamento. Revista Brasileira de Zootecnia, 32(6):1763-1777, 2003.

GARCEZ, B. E. et al. Valor nutritivo do feno de folíolos de pindoba de babaçu submetido a tratamentos alcalinos. Ciência Rural, 44(3):524-530, 2014.

GONÇALVES, A. L. et al. Padrão Nictemeral do pH ruminal e comportamento alimentar de cabras leiteiras alimentadas com dietas contendo diferentes relações volumoso:concentrado. Revista Brasileira de Zootecnia, 30(6):1886-1892, 2001.

GOMES, G. M. F. et al. Biodegradação do bagaço de cana-deaçúcar por microrganismos ruminais de caprinos e ovinos. Bioscience Journal, 31(1): 204-214, 2015.

INSTITUTO BRASILEIRO DE GEOGRAFIA E ESTATÍ́STICA - IBGE. LSPA - Levantamento sistemático da produção agrícola. Safras 2014. Available in: <http://www.sidra.ibge.gov.br/ bda/tabela/protabl.asp?c $=1618 \& z=t \& o=26 \& \mathrm{i}=\mathrm{P}>$. Access in: September, 19, 2015. 
MACEDO, C. A. B. de et al. Comportamento ingestivo de ovinos recebendo dietas com diferentes níveis de bagaço de laranja em substituição à silagem de sorgo na ração. Revista Brasileira de Zootecnia, 36(6):19101916, 2007.

MERTENS, D. R. Regulation of forage intake. In: FAHEY JUNIOR, G. C. (Ed.) Forage quality, evaluation and utilization. Winsconsin: American Society of Agronomy, 1994, p.450-493.

MURTA, R. M. et al. Desempenho e digestibilidade aparente dos nutrientes em ovinos alimentados com dietas contendo bagaço de cana-de-açúcar tratado com óxido de cálcio. Revista Brasileira de Zootecnia, 40(6):1325-1332, 2011.

NATIONAL RESEARCH COUNCIL - NRC. Nutrient requeriments of dairy cattle. $7^{\text {th }}$ ed. Rev. Wasington, D.C., National Academy Press, 2001, 381p.

NATIONAL RESEARCH COUNCIL - NRC. Nutrient requeriments of small ruminants: sheep, goats, cervids, and new world camelids. Wasington, D.C., National Academy Press, 2007. $384 p$.

NUNES, M. U. C.; SANTOS, J. R. dos; SANTOS, T. C. dos. Tecnologia para biodegradação da casca de coco seco e de outros resíduos do coqueiro. Aracaju: Embrapa Tabuleiros Costeiros. Circular Técnica, 46 2007. $5 p$.

PIRES, A. J. V. et al. Bagaço de cana-de açúcar tratado com hidróxido de sódio. Revista Brasileira de Zootecnia, 35(3):953-957, 2006.

ROMÃO, C. O. et al. Fracionamento de carboidratos e degradabilidade ruminal da cana-de-açúcar tratada com óxido de cálcio. Arquivo Brasileiro de Medicina Veterinária e Zootecnia, 65(2):537-546, 2013.
SA, H. C. M. de et al. Consumo e comportamento ingestivo de ovinos mestiços alimentados com torta do babaçu (Orbignya spp.). Bioscience Journal, 31(1):107-113, 2015.

SANTOS, G. T. et al. Determinação da digestibilidade in vitro de gramíneas do gênero Cynodon com uso de diferentes metodologias. Acta Scientiarum. Animal Sciences, 22(3):761-764, 2000.

SCHNEIDER, B. H.; FLATT, W. P. The evaluation of feeds through digestibility experiments. Athens: University Georgia, 1975. 423p.

SENHORAS, E. M. Oportunidades da cadeia agroindustrial do coco verde: do coco verde nada se perde, tudo se desfruta. Revista Urutaguá, $n^{\circ} 5$ - dez/jan/fev/mar. Maringá: UEM, 2004. Available in: <http:// http://www.urutagua.uem. br/005/22eco_senhoras.htm>. Acess in: September, 19, 2015.

SILVA, G. W. V. et al. Degradabilidade in situ das silagens de variedades de cana-de-açúcar com aditivos. Archivos de Zootecnia, 63(241):171-182, 2014.

STATISTICAL ANALYSIS SYSTEM - SAS. Statistical analysis systems user's guide SAS: Version 9.2. Cary, NC, USA: SAS Institute Inc., 2009. 1705p.

VAN SOEST, P. J.; ROBERTSON, J. B.; LEWIS, B. A. Methods for dietary fiber, neutral detergent fiber, and nonstarch polyssacarides in relation to animal nutrition. Journal of Dairy Science, 74(10):3583-3597, 1991.

XENOFONTE, A. R. B. et al. Desempenho e digestibilidade de nutrientes em ovinos alimentados com rações contendo farelo de babaçu. Revista Brasileira de Zootecnia, 37(11):2063-2068, 2008. 
